\title{
Correction to: Development of 21 polymorphic microsatellite markers \\ for the black-banded sea krait, Laticauda semifasciata (Elapidae: Laticaudinae), and cross-species amplification for two other congeneric species
}

\author{
Young Se Hyun ${ }^{1} \cdot$ II-Hun Kim ${ }^{1} \cdot$ Ha Yeun Song ${ }^{1} \cdot$ Daesik Park $^{2} \cdot$ Mamoru Toda $^{3} \cdot$ Tein-Shun Tsai $^{4} \cdot$ Hye Suck An $^{1}$ \\ Published online: 1 March 2018 \\ (c) The Genetics Society of Korea and Springer Science+Business Media B.V., part of Springer Nature 2018
}

\section{Correction to: Genes and Genomics \\ https://doi.org/10.1007/s13258-017-0626-4}

Unfortunately, one of the co-author's family name has been incorrectly published in the original online publication. The correct family name should be Tsai.

The original article can be found online at https://doi.org/10.1007/ s13258-017-0626-4.

Hye Suck An

mgran@mabik.re.kr

1 National Marine Biodiversity Institute of Korea (MABIK), Janghang-eup, Seochun, Chungchungnam 33662, South Korea

2 Division of Science Education, Kangwon National University, Chuncheon, Gangwon 24341, South Korea

3 Tropical Biosphere Research Center, University of the Ryukyus, Nishihara, Okinawa 903-0213, Japan

4 Department of Biological Science and Technology, National Pingtung University of Science and Technology, Neipu Township, Pingtung County, Taiwan, Republic of China 